JPPIPA, Vol. 3 No. 22018
Jurnal Penelitian Pendidikan IPA
http://journal.unesa.ac.id/index.php/jppipa

\title{
PENGARUH MODUL TEMATIK BERBASIS INTEGRASI ISLAM DAN SAINS PADA TEMA ENERGI DAN PERUBAHANNYA TERHADAP HASIL BELAJAR SISWA MI MURNI SUNAN DRAJAT LAMONGAN
}

Oleh:

Silviana Nur Faizah ${ }^{1}$, Minahul Mubin ${ }^{2}$

${ }^{1,2}$ Universitas Islam Lamongan

\begin{abstract}
Abstrak
Modul tematik berbasis integrasi Islam dan sains merupakan bahan ajar yang memuat seluruh kompetensi inti dalam pembelajaran tematik. Pada Modul ini Kompetensi Inti 1 yaitu spiritual termuat dalam bentuk integrasi al-Qur'an dengan materi pada tema energi dan perubahannya. Penelitian ini bertujuan untuk menganalisis pengaruh penggunaan Modul Tematik Berbasis Integrasi Islam dan Sains pada Tema Energi dan Perubahannya terhadap hasil belajar siswa MI Murni Sunan Drajat Lamongan. Penelitian ini merupakan penelitian eksperimen One Group Pre-Test Post-Test dengan menggunakan sampel penelitian di Kelas III A dengan jumlah 36 siswa. Dalam modul ini terdapat materi yang diintegrasikan dengan alQur'an pada tema energi dan perubahannya beserta soal evaluasi. Instrument yang digunakan untuk mengumpulkan data adalah 30 butir tes hasil belajar pretest dan posttest dengan metode analisis gain score dan mean. Hasil penelitian menunjukkan bahwa modul tematik berbasis integrasi islam dan sains pada tema energi dan perubahannya dapat meningkatkan hasil belajar, ditunjukkan berdasarkan hasil rerata gain score 0,32 dengan kategori sedang dan mean posttest $(81,3)>$ pretest $(72,2)$. Modul Tematik Berbasis Integrasi Islam dan Sains pada Tema Energi dan Perubahannya diharapkan mampu mengakomodir kebutuhan intelektual dan spiritual siswa di Madrasah.
\end{abstract}

Kata Kunci: Modul tematik, integrasi Islam dan sains, energi dan perubahannya, dan hasil belajar

\begin{abstract}
Thematic modules based on integrated Islam and science (TMBIIS) are teaching materials that contain all the core competencies in thematic learning. In this module Core 1 Competence refers to spiritual in the form of integration of the Qur'an and material of energi and change. This study aims to analyze the effect of the use of TMBIIS on the Theme of Energi and Change to the learning outcomes of students of MI Murni Sunan Drajat Lamongan. This research is an experimental study of One Group Pre-Test PostTest using a sample of research in Class III A with a total of 36 students. In this module there is material that is integrated with the Qur'an on the theme of energi and change along with evaluation questions. The instrument used consists of 30 items for pretest and posttest. The data are then analyzed quantitaively through $N$-gain score and mean. The results showed that TMBIIS could improve learning outcomes, indicated by the results of the average gain score of 0.32 with the moderate category and the posttest mean (81.3)> pretest (72.2). In general, TMBIIS is expected to be able to accommodate the intellectual and spiritual needs of students in islamic school (MI).
\end{abstract}

Keywords: TMBIIS, integrated Islam and science, energi and change, and learning outcome

(C) 2018 Universitas Negeri Surabaya 


\section{PENDAHULUAN}

Kurikulum 2013 merupakan kurikulum yang digunakan di Indonesia saat ini. Kurikulum ini mempunyai ciri khas pada pembelajaran tematiknya. Pembelajaran tematik disusun sesuai dengan keunikan cara belajar siswa, rancangan belajar dan pembelajaran yang substansial, yaitu menyatukan berbagai mata pelajaran yang berbeda menjadi satu kesatuan makna, kemudian dikaitkan dengan kehidupan nyata. Tujuan Pembelajaran pada kurikulum 2013 termuat dalam empat kompetensi inti yaitu sikap spiritual, sikap sosial, pengetahuan, dan keterampilan yang diharapkan dapat menjadikan siswa yang religius, berkarakter, kreatif, produktif, dan inovatif melalui penguatan nilai-nilai keagamaan, sikap, keterampilan, dan pengetahuan secara terintegrasi (Mulyasa, 2013).

Rumusan keempat kompetensi inti (KI) tersebut tergambarkan dalam Q.S. Ali Imran (3): 189-191. Allah melalui firman-Nya tersebut telah memberikan gambaran bahwasanya ada bentuk integrasi Islam dan sains dalam proses memperoleh pengetahuan dalam pernyataan semua yang diciptakan di bumi ini tidak diciptakan tanpa ada maksudnya sehingga manusia harus berfikir dan mempelajari tandatanda kekuasaan-Nya melalui proses pembelajaran yang melibatkan pengatahuan, sikap dan keterampilannya supaya bertambah Iman dan Taqwa kepada Allah swt.

Pada pelaksanaan pembelajaran tematik ini guru diharapkan mampu menciptakan ide-ide kreatif lebih lanjut salah satunya dengan memanfaatkan alternatif kegiatan yang ada dalam buku panduan guru, atau menciptakan ide-ide pembelajaran sendiri. Kesempatan ini hendaknya dimanfaatkan oleh guru di lingkungan madrasah ibtidaiyah (MI) untuk mampu memuat KI 1-4 dalam pembelajaran tematik (Majid, 2014) satu di antaranya dengan mengintegrasikan antara pembelajaran tematik dan spiritual siswa supaya mereka mampu memperoleh produk/konsep dalam pembelajaran tematik melalui proses ilmiah dan kemudian melalui pembelajaran tersebut siswa akan meyakini adanya tanda-tanda kekuasaan Allah swt.

Madrasah merupakan wahana untuk membina ruh melalui praktik hidup ke-Islaman yakni perancangan dan pengarahan untuk membantu, membimbing, melatih, mengajar dan menciptakan kondisi supaya peserta didik atau lulusannya menjadi muslim yang unggul baik dalam intelektual maupun spiritual. Dengan kata lain, peserta didik mampu mengembangkan pandangan hidup, sikap hidup dan keterampilan hidup yang berperspektif Islam (Muhaimin, 2005).
Modul tematik berbasis integrasi (Esha, 2009) Islam dan sains pada akhirnya merupakan jawaban terhadap tantangan proses pendidikan anak. Modul ini memuat proses untuk mendukung siswa mencapai KI 1-4. Dengan kata lain, modul sangat sesuai untuk mengembangkan potensi siswa sesuai dengan kompetensi yang disyaratkan (Mudlofir, 2011).

MI Murni Sunan Drajat Lamongan merupakan satu dari MI favorit yang terdapat di Lamongan akan tetapi pembelajaran masih menggunakan buku tematik yang di dalamnya hanya memuat $\mathrm{KI}$ 2-4 (sikap, pengetahuan, dan keterampilan) sehingga guru belum secara maksimal memasukkan KI 1 spiritual dalam pembelajaran.

Adanya keselarasan antara tujuan dari pembelajaran tematik dan madrasah sebagaimana telah dijelaskan di atas maka, penggunaan modul tematik berbasis integrasi islam dan sains dalam proses pembelajaran pada tema energi dan perubahannya dapat dijadikan alternatif guru dalam mencapai tujuan pembelajaran yang terumuskan dalam KI 1-4.

Pada praktiknya, penggunaan modul tersebut harus berdasarkan pada dukungan terhadap perolehan hasil belajar yang efektif. Berdasarkan definisinya, hasil belajar merupakan perubahan perilaku sebagai dampak dari belajar (Purwanto, 2009) bentuk pemekaran dari bentuk kecakapankecakapan potensial yang dimiliki seseorang (Sukmadinata, Syaodih, dan Syaodih, 2012). Kecakapan itu kemudian tercermin pada tiga aspek, kognitif, afektif, dan psikomotorik (Suprijono, 2009).

Berdasarkan uraian tersebut penelitian tentang "Pengaruh Modul Tematik Berbasis Integrasi Islam dan Sains Pada Tema Energi dan Perubahannya Terhadap Hasil Belajar Siswa MI Murni Sunan Drajat Lamongan" penting untuk dilaksanakan dengan tujuan untuk mengetahui pengaruh penggunaan modul tematik berbasis integrasi Islam dan sains terhadap hasil belajar siswa di MI Murni Sunan Drajat Lamongan.

\section{METODE}

Penelitian ini merupakan penelitian eksperimen dengan jenis penelitian quasi experimental dengan one group pretest posttest design (Sugiyono, 2010). Kelas kontrol/pembanding tidak digunakan dalam penelitian ini akan tetapi menggunakan pretest dan posttest sehingga pengaruh penggunaan modul tematik berbasis integrasi Islam dan sains dapat diketahui secara pasti. Adapun rancangan pada penelitian ini sebagai berikut.
$O_{1}$
$\mathrm{X}$
$\mathrm{O}_{2}$ 
Keterangan:

$\mathrm{O}_{1}=$ memberikan pretest, untuk mengetahui penguasaan awal siswa terhadap tema Energi dan Perubahannya

$\mathrm{X}=$ memberikan perlakuan pada siswa, yaitu menggunakan Modul Tematik berbasis Integrasi Islam dan Sains pada Tema Energi dan Perubahannya.

$\mathrm{O}_{2}=$ memberikan posttest, untuk mengetahui penguasaan siswa terhadap terhadap tema Energi dan Perubahannya.

Subjek penelitian ini adalah siswa kelas III MI Murni Sunan Drajat Lamongan yang berjumlah 36 siswa. Terdapat dua variable dalam penelitian ini yaitu variable bebas dan variable terikat. Variable bebas yaitu penggunaan modul tematik berbasis integrasi Islam dan sains pada tema energi dan perubahannya dan variable terikat yaitu hasil belajar tema energi dan perubahannya pada siswa kelas III MI Sunan Drajat Lamongan tahun pelajaran 2017/2018.

Metode analisis data pada penelitian ini adalah gainscore dan mean. Uji gain score yang bertujuan untuk mengetahui peningkatan hasil belajar siswa sebelum dan sesudah menggunakan modul tematik berbasis integrasi Islam dan sains. Rumus indeks gain ternormalisasi menurut Meltzer yaitu: (Meltzer: 3)

$$
\text { Indeks Gain }(g)=\frac{\text { skor posttest }- \text { skor pretest }}{\text { skor maksimal }- \text { skor pretest }}
$$

Tingkat perolehan gain score ternormalisasi dikategorikan ke dalam tiga kategori yang ditampilkan pada table berikut.

Tabel 1. Kategori Gain score ternormalisasi

\begin{tabular}{cc}
\hline $\begin{array}{c}\text { Gain skor } \\
\text { ternormalisasi }\end{array}$ & Kategori \\
\hline$(\mathrm{g})>0,7$ & Tinggi \\
$0,7>(\mathrm{g})<0,3$ & Sedang \\
$(\mathrm{g})<0,3$ & Rendah \\
\hline
\end{tabular}

Uji Mean (rerata hitung) digunakan dalam penelitian ini untuk memperoleh informasi sebuah kelompok berdasarkan nilai rata-rata kelompok tersebut. rumus rata-rata (mean) berikut:

$$
\bar{x}=\frac{\sum X i}{n}
$$

Keterangan:

$\bar{x}=$ Mean $($ rata-rata)

$\Sigma=$ Epilson (baca jumlah)

$\mathrm{X}_{\mathrm{i}}=$ Nilai $\mathrm{x}$ ke i sampai ke $\mathrm{n}$

$\mathrm{n}=$ Jumlah individu (Sugiyono, 2010)

\section{HASIL DAN PEMBAHASAN}

\section{A. Deskripsi Hasil pretest dan posttest}

Proses pembelajaran dengan menggunakan modul tematik berbasis integrasi Islam dan sains pada tema energi dan perubahannya berpengaruh terhadap hasil belajar siswa kelas III MI Murni Sunan Drajat Lamongan, hal ini dibuktikan dengan hasil uji gainscore dan mean. Hasil pretest-posttest ditunjukkan pada grafik berikut.

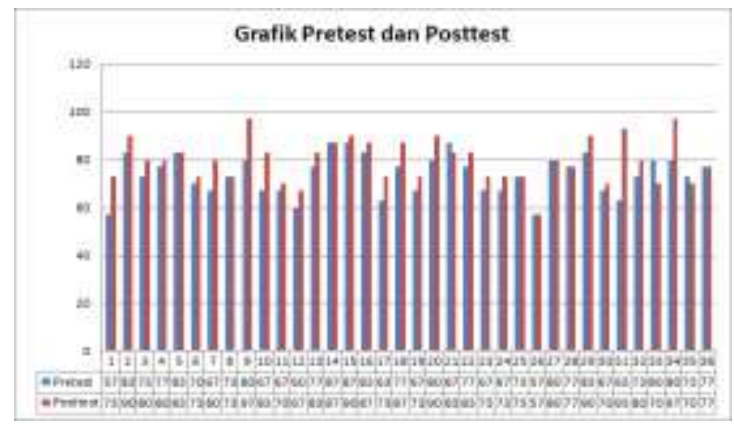

Gambar 1. Grafik tes hasil belajar siswa

\section{B. Hasil Analisis Uji Gainscore dan mean}

Hasil belajar pretest-posttest kemudian dianalisis hasil belajarnya dengan menggunakan gainscore yang ditunjukkan pada grafik berikut.

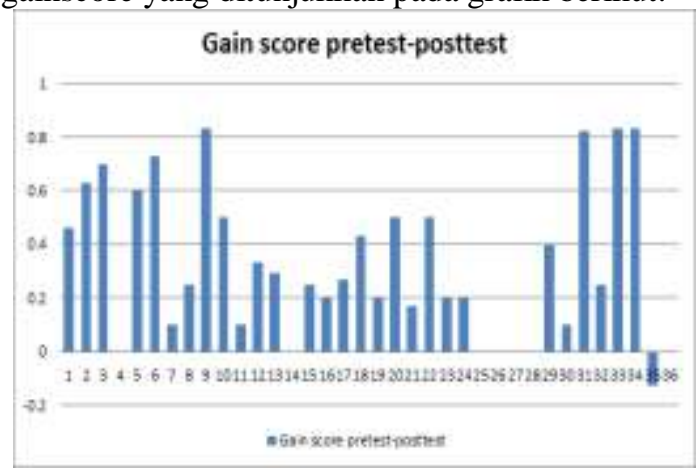

Gambar 2. Grafik gain score pretest-posttest 
Deskripsi hasil perhitungan gain score di kelas III yang berjumlah 36 siswa, terdapat 6 siswa (17\%) berada dalam kategori tinggi, 14 siswa (39\%) berada dalam kategori sedang, dan 16 siswa
(44\%) dalam kategori rendah. Jika disajikan dalam bentuk table hasil perhitungan gain score tersebut adalah sebagai berikut.

Tabel 2. Distribusi Frekuensi Gain score

\begin{tabular}{cccc}
\hline \multirow{2}{*}{ Gain } & \multirow{2}{*}{ Kriteria } & \multicolumn{2}{c}{ Eksperimen } \\
\cline { 3 - 4 } & & $\mathbf{f}$ & $\mathbf{\%}$ \\
\hline $\mathrm{g} \leq 0,3$ & Rendah & 6 & 17 \\
$0,3 \leq \mathrm{g} \geq 0,7$ & Sedang & 14 & 39 \\
$0,7 \geq \mathrm{g}$ & Tinggi & 16 & 44 \\
\hline
\end{tabular}

$\mathrm{N}$ gain score/hasil rerata gain score siswa kelas III yang berjumalh 36 siswa adalah 0,32 dengan kategori sedang, sehingga dapat disimpulkan modul tematik berbasis integrasi Islam dan Sains pada tema energi dan perubahannya berpengaruh terhadap peningkatan hasil belajar siswa kelas III MI Sunan Drajat Lamongan.

Hasil uji analisis mean pretest dan posttest menunjukkan rerata nilai pretest sebesar 72,2 dan rerarta nilai posttest sebesar 81,3. Berdasarkan data tersebut dapat dinyatakan bahwa mean posttest $(81,3)>$ mean pretest $(72,2)$. Jadi dapat disimpulkan bahwa terdapat pengaruh yang signifikan antara sebelum dan sesudah menggunakan modul tematik berbasis integrasi Islam dan Sains pada tema energi dan perubahannya terhadap hasil belajar siswa kelas III MI Murni Sunan Drajat Lamongan.

\section{SIMPULAN}

\section{A. Simpulan}

Berdasarkan penelitian yang telah dilaksanakan, dapat disimpulkan bahwa adanya pengaruh penggunaan modul tematik berbasis integrasi Islam dan sains terhadap peningkatan hasil belajar siswa tema energi dan perubahannya pada siswa kelas III MI Sunan Drajat Lamongan. Hal ini dapat dilihat berdasarkan hasil N-gain score sebesar 0,32 termasuk dalam kategori sedang. Hal tersebut juga dibuktikan dengan hasil mean posttest sebesar 81,3 lebih besar dibanding pretest sebesar 72,2. Selain itu penggunaan modul ini juga dapat dijadikan alternatif bagi guru dalam menyampaikan integrasi keilmuan islam dengan materi pembelajaran. Bagi siswa modul ini dapat digunakan sebagai media dalam menciptakan suasana belajar dengan proses ilmiah sebagai sarana untuk meyakini adanya tanda-tanda kekuasaan Allah SWT.

\section{B. Saran}

Berdasarkan kesimpulan di atas maka, peneliti memberikan rekomendasi kepada pihakpihak terkait sebagai berikut:

1. Pembelajaran dengan menggunakan modul tematik berbasis integrasi Islam dan sains pada tema energi dan perubahannya dapat dijadikan satu dari alternative bagi guru untuk menambah referensi bahan ajar dalam meningkatkan hasil belajar siswa pada tema energi dan perubahannya sekaligus sebagai sarana untuk meyakini adanya tanda-tanda kekuasaan Allah swt.

2. Guru dapat mengembangkan bahan ajar tematik berbasis integrasi Islam dan sains pada tema lain sehingga tercapainya tujuan pembelajaran tematik dalam kurikulum 2013 yang tercermin dalam Kompetensi Inti spiritual, afektif, kognitif dan keterampilan sebagai satu dari upaya dalam mewujudkan visi Madrasah Ibtidaiyah

\section{DAFTAR PUSTAKA}

Esha, Muhammad In'am. 2009. Institutional Transformation. Malang: UIN Maliki Press.

Majid, Abdul. 2014. Pembelajaran Tematik Terpadu. Bandung: PT. Remaja Rosda Karya.

Mudlofir, Ali. 2011. Aplikasi Pengembangan Kurikulum Satuan Pendidikan dan Bahan Ajar dalam Pendidikan Agama Islam. Jakarta: Rajawali Pers.

Muhaimin. 2005. Pengembangan Kurikulum Pendidikan Agama Islam di Sekolah, Madrasah, dan Perguruan Tinggi. Jakarta: PT. Grafindo Persada.

Mulyasa, E. 2015. Implementasi Kurikulum 2013. Bandung: PT. Remaja Rosda Karya.

Purwanto. 2009. Evaluasi Hasil Belajar, Yogyakarta: Pustaka Pelajar. 
Sugiyono. 2010. Statistik untuk Penelitian. Bandung: Alfabeta.

Sukmadinata, Nana Syaodih dan Erliana Syaodih. 2012. Kurikulum dan Pembelajaran
Kompetensi, Bandung: PT. Refika Aditama.

Suprijono, Agus. 2009. Cooperative Learning, Surabaya: Pustaka Belajar. 